\title{
LITERATURA E ARTE: AS FRONTEIRAS EM DISCUSSÃO
}

\begin{abstract}
"Parce qu'ils [texte et image] sont tellement étrangers l'un à l'autre et parce que, en même temps, chacun se discerne dans l'autre: chacun distingue un cerne, un vague contour de soi au fond de l'autre, au fond de son œil ou de sa gorge. Chacun tire l'autre vers soi ou se tire vers lui. C'est toujours en tension. Il y a du tirage, de la traction: pour tout dire, du trait. Ça tire et trace de part et d'autre d'une ligne invisible, non tracée, qui passe entre les deux sans passer nulle part. Ça ne tire et trace peut-être rien d'autre que cette ligne impalpable..."
\end{abstract}

Literatura e arte partilham territórios cada vez mais moventes, de contornos fluidos e bordas permeáveis que incitam ao fluxo constante, não apenas entre as fronteiras disciplinares, mas também entre gêneros, objetos, conceitos. Este número da revista Aletria reúne ensaios que renovam a discussão crítica em torno do tema, ${ }^{2}$ a partir de enfoques teóricos contemporâneos que iluminam a compreensão dos novos produtos culturais, caracterizados pela oscilação, a diluição ou mesmo o apagamento das fronteiras entre Literatura e Arte.

\footnotetext{
${ }^{1}$ NANCY, Jean-Luc. L'oscillation distincte. In: . Au fond des images, Paris: Galilée, 2003. p. 122.

${ }^{2}$ A revista Aletria já havia publicado, em 2006 e 2013, dois números dedicados ao tema da Intermidialidade.
} 
Neste conjunto de ensaios destacam-se, de imediato, a originalidade e a diversidade dos objetos estudados pertencentes tanto aos gêneros canônicos, como o romance e a poesia, quanto às narrativas e às manifestações artísticas híbridas ou compósitas, como a performance, a arquitetura, o design gráfico, a dramaturgia, os quadrinhos, o vídeo, e até fenômenos como as franquias transmidiáticas. Discute-se ainda o lugar que a música, erudita ou pop, passou a ocupar nessa relação, polarizada com frequência entre palavra e imagem, como se constata nos ensaios que a contemplam sob pontos de vista singulares. A condução de uma reflexão teórica - que adquire dimensão transgressora ao deslocar paradigmas para além das dicotomias de fusão ou de separação das artes ditas irmãs - é igualmente ressaltada nos ensaios que revisitam conceitos, propõem métodos ou indicam novos modos de abordar os objetos de pesquisa. A transversalidade das questões permite, enfim, enfatizar algumas linhas de força como o foco na figura do escritor-artista, os intervalos e as zonas de trânsito entre a palavra e a imagem, bem como a discussão teórica sobre a intermidialidade.

O extenso diálogo entre a literatura e as artes, constantemente posto à prova, revela, em síntese, seu aspecto crítico ao mobilizar noções resistentes envolvendo a memória, o tempo e a experiência sensível.

Para este número, contamos com a colaboração das colegas Solange Ribeiro de Oliveira, Eliana Lourenço de Lima Reis e Camila Augusta Pires de Figueiredo na revisão, versão e tradução para o inglês de alguns textos, bem como a de Philippe Enrico, que nos autorizou a publicar a imagem da capa da revista. A contribuição dos pareceristas ad hoc foi igualmente primordial para a realização deste número da Aletria. Nossos agradecimentos a nossos colaboradores e a todos os autores.

Jørgen Bruhn

Márcia Arbex Thaïs F. N. Diniz 


\section{LITERATURE AND THE ARTS: DISCUSSING THE BOUNDARIES}

"This is because they are such strangers to each other and
because, at the same time, each discerns itself in the other:
each one distinguishes a tinge, a vague outline of itself in
the ground of the other, deep in its eye or its throat. Each one
draws the other toward itself or is drawn toward it. There
is always a tension. There is a drawing out [ $d u$ tirage], a
traction: in a word, a line [un trait]. There is an invisible,
untraced line that draws out and traces on both sides, that
passes between the two without passing anywhere. It draws
out and traces nothing, perhaps, but this impalpable line..."

Literature and Arts share increasingly moving territories, with fluid contours and permeable borders that encourage a constant flow not only between disciplinary boundaries but also between genres, objects, concepts. This issue of Aletria brings together essays that renew the critical discussion around the question of intermediality here understood as the study of the transformation and combination of media and art forms. ${ }^{4}$ The volume is based on contemporary theoretical approaches that illuminate the understanding of new cultural products, whose most striking feature is the oscillation, dilution or even erasure of the boundaries between Literature and Arts.

In this collection of essays the originality and diversity of the studied objects immediately stand out: the discussed forms belong to both canonical genres such as romance and poetry as well as narratives in hybrid or composite artistic manifestations, such as performance, architecture, graphic design, dramaturgy, comics, video and even phenomena such as transmedial franchises. Also discussed is the place that music, whether classical or popular, came to occupy in intermedial relationships, whose most recurrent polarity lies between word and image, as it is verified in the essays that contemplate this Art from different points of view. The conduction of a theoretical reflection that acquires a

\footnotetext{
${ }^{3}$ NANCY, Jean-Luc. Distinct Oscillation. In: by Jeff Fort. New York: Fordham University Press, 2005.

. The Ground of image. Translated

${ }^{4}$ In 2006 and 2013 Aletria published two issues dedicated to the theme of Intermediality.
} 
transgressive dimension by moving paradigms beyond the dichotomies of merging or separating the so-called sister arts is also emphasized, by revisiting concepts, proposing methods or indicating new ways of approaching research objects. The characteristic transversality of the questions results in highlighting some lines of force as the focus on the figure of the writer-artist, the intervals and transit zones between word and image, and the theoretical discussion of intermediality.

The extensive dialogue between Literature and Arts, constantly put to the test, reveals, in synthesis, its critical aspect when revisiting notions involving memory, time and sense experiences.

For this issue, we had the collaboration of our colleagues Solange Ribeiro de Oliveira, Eliana Lourenço de Lima Reis and Camila Augusta Pires de Figueiredo, who helped us in the revision and translation of some texts from and into English, and also of Phillippe Enrico, who allowed us the publication of his image on the cover of the journal. Finally, it is important to mention the contribution of the ad hoc reviewers, which was essential for this issue. We are grateful to them all.

Jørgen Bruhn

Márcia Arbex

Thaïs F. N. Diniz 